\title{
ERRATA
}

\section{Mechanisms and Genetics of Resistance to Sodium Lauryl Sulfate in Strains of Shigella and Escherichia coli}

L. M. CORWIN, SARA W. ROTHMAN, ROSALIND KIM, AND L. A. TALEVI

Department of Microbiology, Boston University School of Medicine, Boston, Massachusetts 02118

Volume 4, number 3, page 294, column 1, after last line, add:

\section{ACKNOWLEDGMENTS}

This investigation was supported by the U.S. Army Medical Research and Development Command, Department of the Army, under research contract no. DADA-17-68-M-r146 under the sponsorship of the Commission on Enteric Infections of the Armed Forces Epidemiological Board. S. W. R. was a predoctoral fellow of the National Institutes of Health (GM42132). R. K. is supported by a fellowship under the National Defense Education Act.

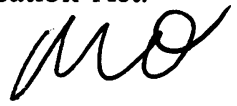

\section{United States Standard Diphtheria Toxin for the Schick Test and the Erythema Potency Assay for the Schick Test Dose}

\author{
MICHAEL F. BARILE, ROBERT W. KOLB, AND MARGARET PITTMAN \\ Division of Biologics Standards, National Institutes of Health, Bethesda, Maryland 20014
}

Volume 4, no. 3, page 295: The title of this paper should be as above instead of "United States Standard Diphtheria Toxin for the Schick Text and the Erythema Potency Assay for the Schick Text Dose." 